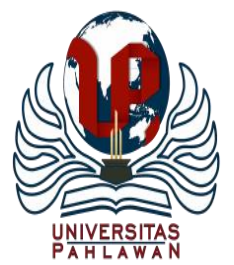

Edukatif : Jurnal Ilmu Pendidikan Volume 3 Nomor 4 Tahun 2021 Halm 1321 - 1336

EDUKATIF: JURNAL ILMU PENDIDIKAN

Research \& Learning in Education

https://edukatif.org/index.php/edukatif/index

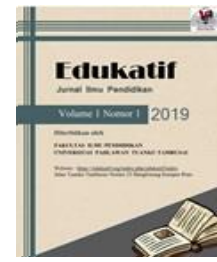

\title{
Analisis Rubrik Penilaian Berbasis Education for Sustainable Development dan Konteks Berfikir Sistem di Sekolah Dasar
}

\author{
Dewi Andriani1 ${ }^{\boxplus}$, Ghullam Hamdu², Karlimah ${ }^{3}$ \\ Universitas Pendidikan Indonesia, Bandung, Indonesia ${ }^{1,2,3}$ \\ E-mail : $\underline{\text { dewiandriani@upi.edu }}^{1}$,ghullamh2012@ upi.edu² ${ }^{2} \underline{\text { karlimah@upi.edu }}^{3}$
}

\begin{abstract}
Abstrak
Penelitian ini bertujuan untuk menganalisis kebutuhan asesmen kinerja menggunakan rubrik penilaian dengan mengaitkan konteks ESD dan berpikir sistem. Metode yang digunakan dalam penelitian ini adalah deskriptif kualitatif. Subjek pada penelitian ini yaitu guru kelas 5 Sekolah Dasar yang ada di Kabupaten Tasikmalaya dan Kota Tasikmalaya berjumlah 6 orang. Data penelitian dikumpulkan melalui teknik wawancara dan studi dokumentasi untuk mengetahui pelaksanaan asesmen kinerja serta identifikasi rubrik yang digunakan oleh guru. Hasil penelitian ini menunjukkan bahwa (1) Semua guru kesulitan dalam menggunakan asesmen kinerja dan instrumen penilaiannya yaitu rubrik. (2) Guru mengalami kesulitan dalam menentukan petunjuk kerja atau deskripsi pada rubrik ditunjukkan dengan hasil analisis dokumen sebesar 37.5\%. (3) Beberapa guru sudah mengetahui mengenai pendidikan untuk pembangunan berkelanjutan atau education for sustainable development (ESD) dimana pembelajarannya lebih terintegrasi seperti dengan lingkungan, sosial, dan ekonomi. (4) Berdasarkan hasil analisis dokumen rubrik terdapat kaitan dengan materi ESD ditunjukan dengan kemunculan konteks lingkungan, sosial, dan ekonomi yaitu sebesar 87,5\%. (5) Kaitan kriteria dengan kemampuan berpikir sistem atau holistik pada rubrik penilaian yang dianalisis sudah terlihat pada tugas dan sesuai tujuan pembelajaran yaitu sebesar $75 \%$.
\end{abstract}

Kata Kunci: konteks ESD, rubrik penilaian, berpikir sistem, asesmen kinerja.

\begin{abstract}
This study aims to analyze the need for performance assessment using a service rubric by linking the context of ESD and systems thinking. The method used in this research is descriptive qualitative. The subjects in this study were grade 5 elementary school teachers in Tasikmalaya Regency and Tasikmalaya City, meaning 6 people. The research data was collected through interview techniques and documentation study to see the implementation of the reports and rubric reports used by the teacher. The results of this study indicate that (1) all teachers have difficulty using the assessment and assessment, namely the rubric. (2) The teacher has difficulty in determining work instructions or descriptions in the rubric which is indicated by the results of document analysis of 37.5\%. (3) Some teachers have seen education for sustainable development (ESD) where learning is more integrated, such as environmental, social, and economic. (4) Based on the results of the analysis of the rubric document referring to the ESD material, it is shown that the emergence of the environmental, social, and economic context is $87.5 \%$. (5) The relationship between the criteria and the holistic or systems thinking ability in the analyzed report has been seen in the assignment and according to the learning objectives of $75 \%$.
\end{abstract}

Keywords: ESD context, assessment, systems thinking, performance assessmen.

Copyright (c) 2021 Dewi Andriani, Ghullam Hamdu, Karlimah

$\triangle$ Corresponding author

Email : dewiandriani@upi.edu

DOI : https://doi.org/10.31004/edukatif.v3i4.514

ISSN 2656-8063 (Media Cetak)

ISSN 2656-8071 (Media Online)

Edukatif : Jurnal Ilmu Pendidikan Vol 3 No 4 Tahun 2021 p-ISSN 2656-8063 e-ISSN 2656-8071 
1322 Analisis Rubrik Penilaian Berbasis Education for Sustainable Development dan Konteks Berfikir Sistem di Sekolag Dasar - Dewi Andriani, Ghullam Hamdu, Karlimah

DOI : https://doi.org/10.31004/edukatif.v3i4.514

\section{PENDAHULUAN}

Penilaian merupakan proses pengumpulan dan pengolahan informasi mengenai hasil belajar untuk menentukan pencapaian hasil belajar peserta didik berupa kegiatan yang berkesinambungan secara sistematis. Penilaian menjadi salah satu komponen penting dalam penyelengaraan pendidikan. Peningkatan kualitas pembelajaran serta kualitas sistem penilaian merupakan upaya untuk meningkatkan kualitas pendidikan (Mansyur, Harun, \& Suratno, 2019:1). Kurikulum pendidikan di Indonesia yang berlaku saat ini yaitu menggunakan Kurikulum 2013. Penggunaan penilaian pada kurikulum 2013 mencakup penilaian pengetahuan, keterampilan, dan sikap. Kurikulum 2013 memberlakukan asesmen autentik atau penilaian autentik, dimana dalam pelaksanaannya tidak membuat peserta didik merasa tertekan atau terpaksa saat mengikuti pembelajaran namun dilaksanakan secara alami (Haqiqi, Ramdani, \& Zulkifli, 2018; Setiawan, Sa'dijah, \& Akbar, 2017).

Menurut Munawati, (2017) asesmen autentik melibatkan peserta didik untuk melakukan kegiatan atau tugas secara nyata agar pembelajaran lebih bermanfaat dan bermakna. Asemen autentik dilaksankan secara komprehensif ketika menilai aspek sikap, pengetahuan, dan keterampilan. Khusus pada asesmen autentik ranah keterampilan dapat digunakan asesmen kinerja. Asesmen kinerja fokus terhadap asesmen proses maupun hasil, yaitu bentuk asesmen yang meminta peserta didik untuk menyelesaikan tugas kinerja untuk menerapkan pengetahuan dan keterampilan yang dimiliki (Setiawan et al., 2017). Sehingga asesmen kinerja (Performance) diharapkan mampu membiasakan peserta didik untuk menunjukukkan kinerjanya berdasarkan penguasaan pengetahuan yang telah dipelajari sebelumnya oleh peserta didik (Pendidikan, 2019).

Prinsip dari penilaian adalah menyeluruh dan berkesinambungan. Asesmen kinerja merupakan penilaian terhadap perolehan serta penerapan pengetahuan, sikap, dan keterampilan yang ditunjukkan oleh kemampuan peserta didik, baik dalam proses maupun produk (Wulan, 2018:8). Dengan demikian, dalam kurikulum 2013 dianjurkan mengenai asesmen kinerja karena peserta didik dituntut dapat mempraktikkan dan mengaplikasikan pengetahuan yang sudah dipelajari ke dalam berbagai macam konteks sesuai dengan kriteria yang diinginkan dalam pembelajaran (Pendidikan, 2019). Dibutuhkan instrumen penilaian yang tepat dan sesuai untuk menilai suatu pembelajaran yang dijadikan sebagai rambu-rambu dalam melaksanakan asesmen kinerja (Kurniawati \& Mawardi, 2021).

Instrumen penilaian yang digunakan dapat berupa rubrik penilaian yang berisikan kategori pencapaian kinerja. Secara sederhana rubrik diartikan sebagai acuan penilaian yang menunjukkan sejumlah kriteria tampilan proses atau hasil kerja peserta didik (Wulan, 2018:43, Mansyur, Harun, \& Suratno, 2019:273). Di dalam rubrik perlu terdapat deskripsi kemampuan aspek/kriteria dan tingkatan-tingkatan sesuai penguasaan dinyatakan dengan menggunakan skor. Misalnya tingkatan penguasaan yang masih kurang mendapatkan skor 1, penguasaan cukup mendapat skor 2, baik mendapatkan skor 3, serta penguasaan yang baik sekali mendapatkan skor 4 (Wulan, 2018:43). Berdasarkan pengertian tersebut penggunaan rubrik dapat memberikan informasi untuk memperbaiki proses pembelajaran serta menilai pencapaian kompetensi dalam pembelajaran (Pendidikan, 2019). Dengan demikian rubrik dijadikan sebagai pedoman asesmen kinerja atau hasil kerja peserta didik yang terdiri atas skor dan kriteria yang harus dipenuhi untuk mencapai skor tersebut (Putri, Nyeneng, \& Rosidin, 2016).

Kurikulum 2013 menggunakan pembelajaran terpadu, dimana pembelajarannya mengaitkan mata pelajaran yang satu dengan yang lainnya. Pendidikan Nasional Indonesia pada dasarnya didedikasikan untuk keseluruhan aspek pembangunan nasional, khususnya pengembangan SDM yaitu bersesuaian dengan tujuan dari kurikulum 2013 yang secara implisit sudah mengarah pada konsep pendidikan pembangunan berkelanjutan atau education for sustainable development (ESD). Seperti adanya penerapan pengetahuan yang tertuang di dalam buku tema kurikulum 2013 yang mengaitkan kehidupan sehari-hari berupa isu-isu lingkungan. Dengan adanya pembelajaran seperti itu diharapkan proses pembelajaran yang berlangsung di 
1323 Analisis Rubrik Penilaian Berbasis Education for Sustainable Development dan Konteks Berfikir Sistem di Sekolag Dasar - Dewi Andriani, Ghullam Hamdu, Karlimah

DOI : https://doi.org/10.31004/edukatif.v3i4.514

sekolah menjadi lebih bemakna dan mengarahkan peserta didik untuk memiliki kesadaran atas nilai-nilai keberlanjutan (Clarisa, Danawan, Muslim, \& Wijaya, 2020).

Pendidikan untuk pembangunan berkelanjutan (ESD) ialah proses pembelajaran yang didasarkan pada cita-cita luhur dan juga prinsip keberlanjutan, memusatkan pada semua tingkatan dan jenis pembelajaran dalam rangka memberikan pendidikan yag berkualitas (Noor Endah Mochtar, Hasnah Gasim, Hendarman, Noor Indrastuti, Aulia Wijiasih, Cecep Suryana, Kurniati Restuningsih, 2014). Pembelajaran dengan menerapkan konteks ESD akan mengarahkan peserta didik belajar mengajukan pertanyaan yang kritis, belajar untuk membayangkan masa depan yang lebih positif dan berkelanjutan, belajar berpikir sistematik, dan diharapkan peserta didik dapat mengatasi permasalahan yang nyata dalam pembelajaran dengan memperhatikan dampak bagi lingkungan, sosial, dan ekonomi (Tilbury, 2011).

Dengan demikian ESD secara tidak langsung sudah tertuang di dalam konsep kurikulum 2013 dengan masalah atau tantangan lingkungan yang ada yaitu terintegrasi pada setiap mata pelajaran dan ada juga yang berdiri sendiri. Nilai-nilai ESD sudah tercakup pada KI dan KD. (UNESCO, 2017). Beberapa Kompetensi Dasar secara eksplisit memuat prinsip pembangunan berkelanjutan. Kompetensi dasar yang tidak memuat prinsip pendidikan berkelanjutan tetap dapat dibuat indikator yang menerapkan prinsip pembangunan berkelanjutan di dalam pembelaarannya (Supriatna, Romadona, Saputri, \& Darmayanti, 2018). Selain itu penting untuk tujuan pembelajaran, metode belajar mengajar, dan ukuran penilaian diselaraskan dengan erat agar saling memperkuat.

Pendidikan merupakan fondasi utama untuk menerapkan ESD maka diharapkan peserta didik memilki kemampuan dan tanggung jawab untuk mulai melestarikan lingkungan, peduli terhadap sosial serta ekonomi. Melalui pembelajaran ESD peserta didik diarahkan untuk memiliki kompetensi berpikir sistem. Peserta didik belajar berpikir sistem yaitu dikenal dengan pemikiran holistik pada dinamika sistem keseluruhan (Clark et al., 2017). ESD atau pendidikan untuk pembangunan berkelanjutan memberikan pengetahuan yang terasa saling bersangkutan, penuh arti dan mengakar dikehidupan sehari-hari anak-anak atau peserta didik (Lundegard, Sellgreen, \& Demetriades, 2020). Menggunakan berpikir sistem, peserta didik akan lebih memahami bahwa perubahan dalam satu bagian sistem dapat mempengaruhi bagian lain yaitu semuanya saling berhubungan.

Penerapan dan penanaman ESD harus dimulai sejak dini, dimana peserta didik mempunyai tanggung jawab untuk menjaga keseimbangan lingkungan, menghubungkan permasalahan tantangan hidup melalui pengetahuan, keterampilan, dan nilai-nilai (Didham \& Ofei-Manu, 2020). Pembelajaran dengan konteks ESD harus terus dilakukan walaupun tersembunyi dan tersirat, misalkan dalam sebuah perangkat yaitu silabus (Syllabus) rencana Pembelajaran (Lesson Plan) dan luarnya adalah tertuang dalam latihan peserta didik dalam berbentuk tugas yang dinyatakan (Worksheet) yaitu dengan melakukan tugas kinerja (Syakur, 2017).

Pembelajaran berkelanjutan atau ESD merupakan pembelajaran yang kompleks. Contohnya dalam tugas mendemonstrasikan pemahaman peserta didik mengenai topik yang kompleks seperti pidato, proyek, dan sebagainya membutuhkan pemikiran mendalam serta penilaian yang sesuai. Salah satu alat untuk menilai tugas kompleks secara sistematis ialah rubrik. Rubrik efektif karena membantu guru dan peserta didik. Dengan menggunakan rubrik pembelajaran menjadi fleksibel karena memungkinkan kedalaman yang lebih ketika mempelajarai berbagai topik misalnya topik keberlanjutan (Lee, 2012).

Di sekolah dasar guru masih kesulitan dalam menggunakan rubrik untuk asesmen kinerja sehingga belum semua guru dapat melaksanakan asesmen kinerja dikarenakan belum mengetahui instrumen yang sesuai yaitu menggunakan rubrik. Listyaningrum \& Winahyu (2017) melaporkan berdasarkan pengamatan awal yang dilakukan di SDN Blimbang 3 Kota Malang yaitu pelaksanaan penilaian kinerja tidak dilakukan selama proses pembelajaran dikarenakan terkendala waktu, namun berdasarkan dokumen RPP ditemukan mengenai perencanaan penilaian kinerja tetapi belum adanya instrumen penilaian yang direncanakan berupa pedoman penskoran. 
1324 Analisis Rubrik Penilaian Berbasis Education for Sustainable Development dan Konteks Berfikir Sistem di Sekolag Dasar - Dewi Andriani, Ghullam Hamdu, Karlimah

DOI : https://doi.org/10.31004/edukatif.v3i4.514

Listiani, Fadiawati, \& Rosilawati, (2016) juga mengungkapkan sebagian besar guru belum membuat instrumen asesmen kinerja begitu juga pelaksanaannya masih kurang, ini disebabkan karena kurangnya pemahaman mengenai asesmen kinerja dan belum pernah membuat instrumen asesmen kinerja. Kemudian dalam menilai unjuk kerja guru mengalami kesulitan karena pedoman penyekoran dalam instrumen tidak jelas, sehingga diabaikan. Komponen-komponen yang dinilai dan jumlah peserta didik yang dinilai juga cukup banyak, sehingga sulit untuk mengambil keputusan (Yudha, Masrukan, \& Djuniadi, 2014).

Ernawati, (2020) menyatakan bahwa kemampuan guru dalam mengembangkan rubrik penilaian masih kurang, guru kesulitan dalam menyesuaikan karakteristik peserta didiknya dengan pedoman penilaian. Kebanyakan rubrik asesmen kinerja yang digunakan guru yaitu menggunakan instrumen penilaian dari buku guru dalam pembuatan RPP baik dalam pembelajaran, bukan dari hasil pengembangan yang dilakukan oleh guru. Terkadang guru hanya mengandalkan ingatannya saja tanpa membawa panduan instrumen penilaian (Kurniasih, Hamdu, \& Lidinillah, 2020). Begitu juga di sekolah dasar khusunya pada penilaian keterampilan biasanya dilakukan tanpa menggunakan instrumen yang khsusu yang sesuai dengan ketentuan sehingga penilaian menjadi subjektif. Minimnya pemahaman guru mengenai rubrik penilaian menyebabkan guru menggunakan rubrik yang sudah ada dalam buku guru yang sulit dipahami (Agustin, Suryana, \& Nugaraha, 2018).

Beberapa penelitian telah dilakukan berkaitan dengan rubrik penilaian. Pertama terkait rubrik asesmen kinerja, Sukreni et al (2014) menyatakan dalam pengumpulan datanya menggunakan metode non tes berupa rubrik penilaian kinerja karena menilai keterampilan berbicara peserta didik. Sementara itu, Ernawati, (2020) untuk meningkatkan kompetensi guru dalam menyusun rubrik penilaian perlu adanya pembinaan secara terstruktur. Pada pembelajaran saat ini yaitu Belajar Dari Rumah (BDR) guru harus menyesuaikan kegiatan belajar sesuai dengan kondisi peserta didik dan orang tua sebagai pendamping dalam pembelajaran dari rumah. Hal ini menyebabkan orang tua peserta didik merasa kebingungan ketika pelaksanaan pembelajaran tanpa disediakan rubrik penilaian proses dan belajar peserta didik yang diberikan oleh guru (Winarni, 2021). Kemudian Dewi, Asyar, \& Hariyadi, (2016) melaporkan bahwa untuk mengukur kemampuan peserta didik baik pengetahuan maupun keterampilan yaitu menggunakan instrumen dengan dilengkapi rubrik penilaian yang sesuai dengan komponen kegiatan.

Kedua, terkait dengan analisis rubrik peniaian Andini, Sulistiono, \& Budiretnani (2014) melaporkan terkait kualitas rubrik penilaian pada Rencana Pelaksanaan Pembelajaran (RPP) yang disusun oleh guru kelas IV SD di Kota Kediri yaitu sebanyak 15 RPP kelas IV Semester 1 diambil secara acak. Muhammad \& Mukhlis (2021) menyelidiki rubrik analitik dan rubrik holistik yang diperoleh dari RPP Bahasa Indonesia sesuai dengan tahapan merancang rubrik yaitu komponen kriteria, bobot, tingkat kinerja, dan skor. Sementara itu, Listyaningrum \& Winahyu (2017) menyelidiki melalui studi kasus mengenai perencanaan, penerapan, dan pelaporan penilaian kinerja menggunakan rubrik penilaian. Terakhir, terkait pengembangan rubrik penilaian. Nurlenasari, Lidinillah, Nugraha, \& Hamdu, (2019) mengembangkan instrumen penilaian kinerja untuk mengukur kompetensi abad 21 dalam pembelajaran STEM yang terdiri dari kriteria, skor prestasi, deskripsi skor prestasi.

Berdasarkan penjelasan tersebut dapat disimpulkan bahwa rubrik penilaian yang berkaitan dengan asesmen kinerja atau keterampilan perlu dikaji dan dipelajari meliputi kriteria, deskripsi, tingkat kinerja, dan skor/bobot. Belum semua guru menggunakan rubrik penilaian dalam pembelajarannya. Sehingga berdasarkan latar belakang tersebut, penelitian ini bertujuan untuk mencari tahu penggunaan rubrik asesmen kinerja dan komponen rubrik di sekolah dasar dengan mengaitkan ESD atau pendidikan untuk pembangunan berkelajutan pada kurikulum 2013 serta konteks berpikir sistem peserta didik. 
1325 Analisis Rubrik Penilaian Berbasis Education for Sustainable Development dan Konteks Berfikir Sistem di Sekolag Dasar - Dewi Andriani, Ghullam Hamdu, Karlimah

DOI : https://doi.org/10.31004/edukatif.v3i4.514

\section{METODE PENELITIAN}

Penelitian ini menggunakan pendekatan deskriptif kualitatif. Jenis penelitian deskiptif kualitatif adalah metode penelitian yang memanfaatkan data kualitatif kemudian dijabarkan secara deskriptif dan cenderung menggunakan analisis. Penelitian deskriptif ditunjukkan untuk menggambarkan atau mendeskripsikan suatu fenomena yang ada, baik fenomena alamiah maupun rekayasa manusia (Pratiwi, Arharina, \& Saputra, 2020; Yunitasari \& Hanifah, 2020). Penelitian ini difokuskan pada kegiatan mendeskripsikan jenis rubrik penilaian yang digunakan dan komponen rubrik penilaian di Sekolah Dasar dengan mengaitkan konteks ESD atau pendidikan untuk pembangunan berkelanjutan dan kompetensi berpikir sistem. Untuk mendeskripsikan komponen rubrik penilaian yaitu dengan menganalisis RPP yang disusun oleh guru serta buku guru tema 5 subtema 2 "Hubungan Antar Makhluk Hidup dalam Ekosistem" di kelas V. Pengumpulan data dalam penelitian ini merujuk pada hasil wawancara kepada guru kelas V serta dilengkapi dengan studi dokumentasi yang nantinya akan dianalisis terkait komponen-komponen yang ada pada rubrik penilaian.

Penelitian ini dilakukan di 4 Sekolah Dasar yang ada di Kota dan Kabupaten Tasikmalaya yaitu SDN 1 Kalangsari bertempat di Kota Tasikmalaya. SDN Sukasenang, SDN Jayaraga, dan SDN Poponcol bertempat di Kabupaten Tasikmalaya. Pemilihan tempat didasarkan pada karakteristik kurikulum dan pembelajaran. Penelitian ini melibatkan partisipan yaitu seorang guru yang mengajar sebagai wali kelas V dari 4 Sekolah Dasar yang terpilih, Terdiri dari 2 guru dari SDN Kalangsari, 2 guru dari SDN Sukasenag, 1 guru dari SDN Jayaraga, dan 1 guru dari SDN Poponcol.

Teknik pengumpulan data yaitu wawancara dan studi dokumentasi. Wawancara yang digunakan dalam penelitian ini yaitu wawancara semi terstruktur. Peneliti telah menyiapkan draf pertanyaan kemudian melakukan wawancara dengan seluruh informan mengenai pelaksanaan penilaian asesmen kinerja menggunakan rubrik penilaian serta kaitan ESD dalam pembelajaran kurikulum 2013. Instrumen yang digunakan yaitu pedoman wawancara. Berikut merupakan kisi-kisi pedoman wawancara yang digunakan dalam Tabel 1.

Tabel 1. Pedoman Wawancara

\begin{tabular}{|l|l|l|l|}
\hline No & \multicolumn{1}{|c|}{ Aspek } & \multicolumn{1}{|c|}{ Indikator } \\
\hline 1 & $\begin{array}{l}\text { Mengetahui penggunaan asesmen kinerja di } \\
\text { sekolah dasar }\end{array}$ & $\begin{array}{l}\text { a. Penerapan } \\
\text { b. Kendala pengunaan } \\
\text { c. Manfaat } \\
\text { d. Pedoman penilaian }\end{array}$ \\
\hline 2 & $\begin{array}{l}\text { Mengetahui penggunaan rubrik asesmen } \\
\text { kinerja pada pembelajaran di sekolah dasar }\end{array}$ & $\begin{array}{l}\text { a. Penerapan } \\
\text { b. Komponen rubrik } \\
\text { c. Kendala penggunaan }\end{array}$ \\
\hline 3 & $\begin{array}{l}\text { Mengetahui kesulitan pembuatan rubrik } \\
\text { asesmen kinerja pada pembelajaran di } \\
\text { sekolah dasar }\end{array}$ & $\begin{array}{l}\text { a. Kesulitan dalam membuat rubrik } \\
\text { penggunaan prinsip Education For } \\
\text { Suistainable Development (ESD) sebagai } \\
\text { pendekatan pembelajaran kurikulum 2013 di } \\
\text { sekolah dasar }\end{array}$ & $\begin{array}{l}\text { a. Kaitan pembelajaran tematik dengan materi } \\
\text { lingkungan, sosial, dan ekonomi } \\
\text { bendidikan untuk pembanguan berkelanjutan }\end{array}$ \\
\hline 5 & $\begin{array}{l}\text { Menjelaskan penerapan kompetensi berpikir } \\
\text { sistem pada pembelajaran tematik } \\
\text { kurikulum 2013 di sekolah dasar }\end{array}$ & $\begin{array}{l}\text { a. Kemampuan dalam mengintegrasikan materi } \\
\text { lingkungan, sosial, dan ekonomi dalam } \\
\text { pembelajaran. } \\
\text { b. Manfaat }\end{array}$ \\
\hline
\end{tabular}


1326 Analisis Rubrik Penilaian Berbasis Education for Sustainable Development dan Konteks Berfikir Sistem di Sekolag Dasar - Dewi Andriani, Ghullam Hamdu, Karlimah

DOI : https://doi.org/10.31004/edukatif.v3i4.514

Pedoman wawancara di atas digunakan untuk menyusun instrumen wawancara pada guru untuk mengetahui penggunaan rubrik asesmen kinerja serta bagaimana kaitan pendidikan untuk pembangunan berkelanjuta dengan kurikulum 2013 dan kompetensi berpikir sistem di sekolah dasar.

Studi Dokumentasi dilakukan pada dokumen-dokumen yang ada di Sekolah Dasar yaitu menganalisis dokumen mengenai rubrik penilaian pada RPP dan buku guru. Instrumen yang digunakan ialah daftar check list. Berikut merupakan pedoman studi dokumentasi berupa daftar check list dapat dilihat dalam Tabel 2.

Tabel 2. Kisi-kisi Studi Dokumentasi

\begin{tabular}{|c|c|c|c|}
\hline No & Aspek & Indikator & $\begin{array}{c}\text { Butir } \\
\text { Pernyataan }\end{array}$ \\
\hline \multirow{4}{*}{1} & \multirow{4}{*}{ Cakupan Isi } & Isi rubrik & 1 \\
\hline & & Kaitan rubrik dengan kompetensi atau tujuan pembelajaran & 2 \\
\hline & & Kemunculan konteks lingkungan, sosial, dan ekonomi & 3 \\
\hline & & Kaitan kriteria dengan kemampuan berpikir sistem & 4 \\
\hline \multirow{2}{*}{2} & \multirow{2}{*}{ Kejelasan } & Kejelasan kata-kata dalam rubrik & 5 \\
\hline & & Ketepatan penskoran atau pemberian point & 6 \\
\hline 3 & Tingkat Kinerja & Kejelasan petunjuk kerja atau deskripsi & 7 \\
\hline \multirow{2}{*}{4} & \multirow{2}{*}{ Kepraktisan } & Skala peringkat & 8 \\
\hline & & Kriteria-kriteria di dalam rubrik & 9 \\
\hline 5 & Kualitas teknis & Objektivitas penilaian & 10 \\
\hline
\end{tabular}

Penelitian ini menggunakan triangulasi sumber dan triangulasi teknik pengumpulan data untuk memeriksa keabsahan data. Triangulasi sumber digunakan dengan cara melakukan wawancara kepada guru kelas V. Sedangkan triangulasi teknik pengumpulan data dilakukan dengan menganalisis dokumen-dokumen penting yang berhubungan. Kemudian dicek kembali data hasil wawancara dengan data hasil studi dokumentasi. Jika dari triangulasi menghasilkan data yang sama dan berkaitan maka data dapat dipercaya kebenarannya.

Penelitian ini menggunakan analisis data meliputi kondensasi data, penyajian data, serta pengambilan kesimpulan dan verifikasi data (Miles, Huberman, \& Saldana, 2014). Peneliti awalnya menstranskripsikan hasil wawancara dengan semua informan yaitu guru kelas V. Kemudian peneliti melakukan penyajian data dan terakhir yaitu melakukan pengambilan kesimpulan.

\section{HASIL DAN PEMBAHASAN PENELITIAN}

\section{Penggunaan Rubrik di Sekolah Dasar}

Berdasarkan penelitian diketahui bahwa ketika pembelajaran guru sudah mengetahui terkait menggunakan jenis penilaian sikap, pengetahuan, dan keterampilan. Tetapi yang sering digunakan adalah penilaian soal tes. Penilaian pada ranah keterampilan biasanya menggali kemampuan-kemampuan peserta didik dengan mengerjakan tugas-tugas secara nyata yang menunjukkan unjuk kerja. Berkaitan dengan asesmen kinerja atau penilaian kinerja hanya sebagian guru yang pernah menggunakannya dalam pembelajaran begitu juga dengan pedoman dalam menggali kemampuan-kemampuan tugas kinerja yaitu rubrik masih sangat kurang dalam pelaksanannya. Dalam menilai suatu tugas kinerja dibutuhkan pembelajaran yang kompleks. Pembelajaran kurikulum 2013 yaitu pembelajaran tematik, dimana dalam pembelajarannya telah mengaitkan materi lingkungan, sosial, dan ekonomi dibuktikan dengan kesesuian materi dengan pembelajaran pada buku tema. Dengan demikian pembelajaran kurikulum 2013 sebenarnya sudah mengenalkan mengenai aspek lingkungan, sosial, dan ekonomi dimana ketiga aspek tersebut merupakan pilar dari pendidikan untuk pembangunan berkelanjutan atau education for sustainable development (ESD). 
1327 Analisis Rubrik Penilaian Berbasis Education for Sustainable Development dan Konteks Berfikir Sistem di Sekolag Dasar - Dewi Andriani, Ghullam Hamdu, Karlimah

DOI : https://doi.org/10.31004/edukatif.v3i4.514

Melalui pembelajaran yang mengenalkan materi lingkungan, sosial, dan ekonomi secara bersamaan dan berkaitan akan membantu peserta didik untuk berpikir secara holistik atau di dalam ESD dikenal dengan kompetensi berpikir sistem. Hal ini sesuai dengan hasil wawancara yang dilakukan pada keenam guru di sekolah dasar Kabupaten Tasikmalaya dan Kota Tasikmalaya, yang dilaksanakan pada akhir Maret 2021 dan awal April 2021.

\section{Penggunaan Rubrik Penilaian di SDN Kabupaten Tasikmalaya}

Berdasarkan hasil wawancara di SDN Sukasenang dengan dua orang guru yaitu guru kelas VB dan VC menyebutkan bahwa di kelas VB penilaian yang digunakan dalam pembelajaran yaitu penilaian berbentuk tes dan terkadang penilaian keterampilan menggunakan rubrik. Pengunaan asesmen kinerja sudah pernah dilaksanakan tetapi hanya terbatas pada produk dan projek saja bukan kepada prosesnya dan langsung dinilai tanpa menggunakan instrumen penilaian. Guru kesulitan dalam menentukan tugas-tugas atau kinerja peserta didik yang akan dinilai karena seringnya langsung menilai produk. Begitu juga dengan rubrik, biasanya menggunakan rubrik yang terdapat pada buku guru dan mengadaptasi dari buku guru. Berkaitan dengan indikator atau kriterianya juga dipilih-pilih dari buku yang sudah ada yaitu buku guru. Kemudian adanya kendala waktu dan beban guru yang harus dikerjakan sehingga untuk mengembangkan rubrik penilaian seringkali mengalami kesulitan.

Kemudian di kelas VC juga memiliki kendala yang sama yaitu kendalanya waktu, sehingga penilaian menggunakan rubrik jarang dilaksanakan dan fokus pada pengetahuan peserta didik. Guru sudah paham mengenai asesmen kinerja dan pernah menggunakannya. Asesmen kinerja tidak dilaksanakan setiap hari tetapi pada pembelajaran tertentu saja. Alasannya karena asesmen kinerja dilaksanakan secara menyeluruh, harus mengingat peserta didik yang begitu banyak sehingga merasa kesulitan dalam melaksanakannya. Dalam pelaksanaan untuk menilai kinerja sudah menggunakan pedoman yairu rubrik. Rubrik disesuaikan dengan pembelajaran dan menilai indikator keterampilan, apakah keterampilan proses atau produk. Rubrik yang digunakan yaitu rubrik yang ada pada buku guru terkadang juga membuat rubrik sendiri tetapi dalam pelaksanaannya digunakan dengan hanya mengingat saja.

Berkaitan dengan pembelajaran kurikulum 2013 di SDN Sukasenang secara tidak langsung sudah diajarkan mengenai materi lingkungan, sosial, dan ekonomi, karena sudah ada pada buku tema. Pembelajarannya juga sudah mengarah kepada pendidikan untuk pembangunan berkelanjutan, dimana guru mengaitkan permasalahan yang terjadi dalam kehidupan sehari-hari bisa juga dilengkapi dengan tugas-tugas kinerja misalnya dalam masalah sampah, peserta didik ditugaskan membuat salah satu kerajinan dari sampah plastik. Pembelajaran tersebut sudah ada pada buku tema, sehingga tujuan dari mengaitkan pendidikan untuk pembangunan berkelanjutan yaitu peserta didik mampu berpikir secara sistem atau kemampuan berpikir sistem. Kemampuan berpikir sistem dapat diajarkan di sekolah dasar karena dengan kemampuan berpikir sistem peserta didik dapat menghubungkan permasalahan yang diketahuinya (baik permasalahan lingkungan, sosial dan ekonomi), mencari tahu bagaimana harus berinteraksi dalam mengatasi permasalahan tersebut, dan pada akhirnya menjadi suatu budaya yang baik bagi peserta didik.

Selanjutnya berdasarkan hasil wawancara di SDN Jayaraga dengan guru kelas V, menunjukkan beberapa hal yang diperhatikan yaitu penilaian yang sering digunakan adalah penilaian kognitif. Guru mengalami kesulitan dalam pembuatan rubrik untuk sikap dan keterampilan. Berkaitan dengan asesmen kinerja, pernah dilaksanakan dalam pembelajaran tetapi tidak menggunakan pedoman penilaian rubrik hanya langsung saja diberi penilaian untuk setiap anak. Kendala yang lain dalam pelaksanaan asesmen kinerja yaitu bingung dalam mengatur waktunya karena yang dinilai tidak satu orang tetapi satu kelas. Rubrik yang digunakan untuk menilai kinerja pada pembelajaran yaitu mengambil dari buku paket kurikulum 2013 dan belum pernah merancang sendiri. Pembelajaran di SDN Jayaraga menggunakan kurikulum 2013 dimana dalam pelaksanaanya sudah mengaitkan materi lingkungan, sosial, dan ekonomi sesuai dengan pendidikan untuk pembangunan berkelanjutan atau ESD. Hanya saja para guru tidak menyadari hal tersebut karena belum 
1328 Analisis Rubrik Penilaian Berbasis Education for Sustainable Development dan Konteks Berfikir Sistem di Sekolag Dasar - Dewi Andriani, Ghullam Hamdu, Karlimah

DOI : https://doi.org/10.31004/edukatif.v3i4.514

menemukan seminar ataupun sosialisasi mengenai ESD. Penerapanya yaitu dengan cara membiasakan peserta didik melakukan hal-hal sederhana. Seperti belajar menanam pohon di lingkungan rumah, bersama-sama memungut sampah yang berserakan di lingkungan sekolah, dan lain sebagainya. Intinya tanamkan terlebih dahulu sikap pembiasaan yang baik bagi anak yang akan berdampak untuk masa sekarang dan di masa depan baik secara lingkungan, sosial dan ekonomi. Sehingga dengan peserta didik melakukan pembiasaan seperti itu akan muncul pada diri peserta didik mengenai kemampuan yang mampu menghubungkan antar konsep.

Kemudian berdasarkan hasil wawancara di SDN Poponcol dengan guru kelas V menyebutkan bahwa dalam penilaian yang sering digunakan yaitu berkaitan dengan soal tes. Kurangnya pemahaman mengenai asesmen kinerja, karena tidak cukup sekali dua kali dalam penilaiannya. Asesmen kinerja membutuhkan banyak kriteria dan harus dilakukan juga di setiap pembelajaran, sehingga dianggap tidak penting dan jarang dilaksanakan, masih fokus pada pengetahuan. Terkait menilai ranah keterampilan atau psikomotorik biasanya menggunakan rubrik penilaian yang ada di silabus atau buku guru sesuai kurikulum 2013 yang dirasa sudah sesuai. Belum adanya perancangan rubrik buatan sendiri. jika harus membuat rubrik sendiri, guru kesulitan dalam menentukan kriterianya yang sesuai dengan materi dan tujuan pembelajaran. Pembelajaran di dalam kurikulum 2013 sudah mengajarkan mengenai materi lingkungan, sosial, dan ekonomi yaitu dengan adanya tema-tema dalam pembelajarannya mengikuti buku paket Kemendikbud. Guru belum mengenal mengenai konsep ESD atau pendidikan untuk pembangunan berkelanjutan tetapi lebih keintegrasi mata pelajaran. Sebagai contoh yaitu usaha menanamkan hidup bersih kepada peserta didik. Melalui pendidikan untuk pembangunan berkelanjutan membuat peserta didik belajar kemandirian, terbiasa materi-materi yang diintegrasikan, dan tetap harus jelas topiknya. Dengan mengaitkan pendidikan untuk pembanguan berkelanjutan dalam pembelajaran peserta didik mampu belajar berpikir sistem. Untuk mengajarkan kemampuan berpikir sistem kepada peserta didik sekolah dasar itu tergantung kepada konteksnya. Bisa diajarkan karena memang penting dan sebenarnya sudah diajarkan hanya saja tidak secara gamblang berpikir sistem.

Berdasarkan penjabaran di atas diketahui bahwa dalam melaksanakan asesmen kinerja dengan pedoman penskoran yaitu rubrik masih terdapat beberapa kendala diantarannya: kesulitan dalam menentukan tugastugas kinerja, kendala waktu dalam menilai keseluruhan peserta didik, masih kurangnya pemahaman mengenai komponen rubrik sebagai pedoman penskoran yaitu dalam menentukan kriteria. Dalam penilaian guru masih sering menggunakan penilaian pengetahuan soal tes. Kemudian terkait pembelajaran yang mengaitkan materi lingkungan, sosial, dan ekonomi secara tidak langsung sudah diajarkan dalam kurikulum 2013 yaitu sesuai dengan buku tema yang mencerminkan tema-tema pendidikan untuk pembangunan berkelanjutan atau ESD.

\section{Penggunaan Rubrik Penilaian di SDN Kota Tasikmalaya}

Berdasarkan hasil wawancara di SDN 1 Kalangsari Kota Tasikmalaya kepada guru kelas VA dan kelas VB menyebutkan bahwa di kelas VA penilaian kinerja sudah dilakukan namun terkendala banyaknya peserta didik dan waktu. Sehingga penilaian yang sering digunakan yaitu soal tes, walaupun di RPP ada yang menggunakan rubrik pada aspek keterampilan. Ketika mengisi rubrik hanya menggunakan hafalan saja atau diingat barulah diisi rubriknya. Untuk indikator biasanya mengambil dari yang sudah ada, kemudian mencari batasannya sesuai dengan pembelajaran yang akan dipelajari. Kesulitan membuat rubrik sendiri yaitu terkait kriterianya.

Selanjutnya menurut guru kelas VB memaparkan bahwa jenis penilaian yang digunakan yaitu soal tes dan penilaian kinerja. Penilaian kinerja biasanya dalam pembelajaran sains, tetapi karena sekarang kurikulumnya tematik secara umum penilaian kinerja harus ada disetiap pembelajaran. Guru mengalami kesulitan terkait tugas-tugasnya, dibutuhkan sebuah bahan ajar atau media yang dapat memunculkan tugastugas yang jelas, misalnya menggunakan LKS. Untuk penggunaan rubrik pada asesmen kinerja yaitu penilaian kinerjanya tentu menilai kinerja yang dilakukan diluar dari instruksi atau tugas dari LKS, jadi yang ditilai 
1329 Analisis Rubrik Penilaian Berbasis Education for Sustainable Development dan Konteks Berfikir Sistem di Sekolag Dasar - Dewi Andriani, Ghullam Hamdu, Karlimah

DOI : https://doi.org/10.31004/edukatif.v3i4.514

rubrik bukan hasil kerja tugas tapi aspek lain dalam menyelesaikan tugasnya (menggunakan beberapa kriteria). Oleh karena itu guru jarang menggunakan rubrik, jika digunakan aspeknya masih kurang sesuai dan frekuensi penilaiannya menjadi tidak teratur, sehingga masih mengandalkan soal tes. Jika menggunakan rubrik dalam pembelajaran masih mengikuti format dalam silabus yaitu dari buku guru. Terkadang tidak digunakan karena pembelajarannya sering dimodifikasi. Permasalahan yang lain berkaitan dengan indikator yang menjadi kriteria dalam asesmen kinerja belum terlihat secara jelas, serta belum sesuai dengan waktu dan ketuntasan.

Berkaitan dengan pembelajaran kurikulum 2013, materi mengenai lingkungan, sosail, dan ekonomi sudah dipelajari. Dengan catatan tentu lingkungan pasti selalu dibawa dalam pembelajaran, dengan aspek ekonomi dan sosial melengkapinya. Ketika pembelajaran mengintegrasikan ketiga aspek pendidikan untuk pembangunan berkelanjutan yaitu lingkungan, sosial, dan ekonomi akan membantu peserta didik untuk memunculkan pamahaman konsep dengan meningkatkan daya ingat melalui proses-proses dalam mencapai hasil pembelajaran. Membiasakan anak dalam sebuah sistem tentu akan mendukung munculnya penelaahan sistem.

Dilihat dari penjelasan diatas diketahui bahwa penggunaan rubrik asesmen kinerja masih mengalami beberapa kendala dalam penggunaannya yaitu sulitnya membuat rubrik sendiri, biasanya asesmen kinerja dilaksanakan pada pembelajaran sains tetapi sekarang pembelajarannya tematik sehingga sulit dalam menentukan tugas-tugas kinerja serta kriteria untuk rubrik penilaianya. Kemudian terkait pembelajaran 2013 pada pelaksanaanya sudah mengaitkan materi lingkungan, sosial, dan ekonomi.

\section{Komponen Rubrik Penilaian}

Selain wawancara, dilakukan juga analisis studi dokumentasi mengenai dokumen asesmen kinerja yang digunakan di sekolah dasar. Dokumen yang dikaji adalah rubrik penilaian dari RPP dan buku guru. Peneliti mengambil sampel RPP dari 2 sekolah dikarenakan 2 sekolah lagi menggunakan RPP satu lembar sehingga tidak dicantumkan rubrik penilainnya. Kemudian buku guru kelas V Tema 5 Subtema 2, karena asesmen kinerja dari keempat SD berpedoman kepada rubrik yang ada pada buku guru. Analisis menggunakan daftar checklis terdiri dari 10 pernyataan, yang masing-masing memiliki jawaban ya $(\checkmark)$ dan tidak $(x)$. Hasil analisis dokumen asesmen kinerja ditunjukkan dengan Tabel 3.

Tabel 3. Hasil Analisis Dokumentasi RPP dan Buku Guru

\begin{tabular}{|c|c|c|c|c|c|c|c|c|c|c|}
\hline \multirow{2}{*}{ Indikator } & \multirow{2}{*}{ Pernyataan } & \multirow{2}{*}{$\begin{array}{r}\mathbf{R P P} \\
\mathbf{1}\end{array}$} & \multirow{2}{*}{$\begin{array}{c}\text { RPP } \\
2\end{array}$} & \multicolumn{6}{|c|}{$\begin{array}{c}\text { Buku Guru Kelas } 5 \text { Tema } 5 \text { Subtema } \\
2\end{array}$} & \multirow{2}{*}{$\%$} \\
\hline & & & & $\begin{array}{c}\text { PB } \\
1\end{array}$ & $\begin{array}{c}\text { PB } \\
2\end{array}$ & $\begin{array}{c}\mathbf{P B} \\
\mathbf{3}\end{array}$ & $\begin{array}{c}\text { PB } \\
4\end{array}$ & $\begin{array}{c}\mathbf{P B} \\
5\end{array}$ & $\begin{array}{c}\text { PB } \\
6\end{array}$ & \\
\hline Isi rubrik & $\begin{array}{l}\text { Isi dalam rubrik lengkap, } \\
\text { selektif, dan relevan. }\end{array}$ & $x$ & $x$ & $\checkmark$ & $\checkmark$ & $\checkmark$ & $\checkmark$ & $\checkmark$ & $x$ & $62.5 \%$ \\
\hline $\begin{array}{l}\text { Kaitan } \\
\text { rubrik } \\
\text { dengan } \\
\text { kompetensi } \\
\text { atau tujuan } \\
\text { pembelajar } \\
\text { an }\end{array}$ & $\begin{array}{lr}\text { Rubrik } & \text { memiliki } \\
\text { hubungan erat dengan } \\
\text { kompetensi atau tujuan } \\
\text { pembelajaran dengan } \\
\text { hubungan tersebut mudah } \\
\text { diidentifikasi dalam } \\
\text { kriteria penilaian. }\end{array}$ & $x$ & $\checkmark$ & $\checkmark$ & $\checkmark$ & $\checkmark$ & $\checkmark$ & $\checkmark$ & $x$ & $75 \%$ \\
\hline $\begin{array}{l}\text { Kemuncula } \\
\mathrm{n} \text { konteks } \\
\text { lingkungan } \\
\text {, sosial, dan } \\
\text { ekonomi }\end{array}$ & $\begin{array}{l}\begin{array}{l}\text { Isi dalam rubrik } \\
\text { memunculkan konteks } \\
\text { lingkungan, sosial, dan } \\
\text { ekonomi }\end{array}\end{array}$ & $\checkmark$ & $\checkmark$ & $\checkmark$ & $\checkmark$ & $\checkmark$ & $\checkmark$ & $\checkmark$ & $x$ & $87.5 \%$ \\
\hline $\begin{array}{l}\text { Kaitan } \\
\text { kriteria }\end{array}$ & $\begin{array}{rr}\text { Rubrik } & \text { menggunakan } \\
\text { kriteria } & \text { kemampuan }\end{array}$ & $x$ & $\checkmark$ & $\checkmark$ & $x$ & $\checkmark$ & $\checkmark$ & $\checkmark$ & $\checkmark$ & $75 \%$ \\
\hline
\end{tabular}


1330 Analisis Rubrik Penilaian Berbasis Education for Sustainable Development dan Konteks Berfikir Sistem di Sekolag Dasar - Dewi Andriani, Ghullam Hamdu, Karlimah

DOI : https://doi.org/10.31004/edukatif.v3i4.514

\begin{tabular}{|c|c|c|c|c|c|c|c|c|c|c|}
\hline $\begin{array}{l}\text { dengan } \\
\text { kemampua } \\
\mathrm{n} \text { berpikir } \\
\text { sistem }\end{array}$ & $\begin{array}{l}\text { berpikir sistem atau } \\
\text { holistic }\end{array}$ & & & & & & & & & \\
\hline $\begin{array}{l}\text { Kejelasan } \\
\text { kata-kata } \\
\text { dalam } \\
\text { rubrik }\end{array}$ & $\begin{array}{lr}\text { Kata-kata } & \text { yang } \\
\text { digunakan sesuai dan } \\
\text { spesifik dengan aspek } \\
\text { kinerja yang dinilai. }\end{array}$ & $x$ & $x$ & $\checkmark$ & $x$ & $\checkmark$ & $\checkmark$ & $\checkmark$ & $x$ & $50 \%$ \\
\hline $\begin{array}{l}\text { Ketepatan } \\
\text { penskoran } \\
\text { atau } \\
\text { pemberian } \\
\text { point }\end{array}$ & $\begin{array}{l}\text { Pemberian skor atau point } \\
\text { jelas. }\end{array}$ & $\checkmark$ & $\checkmark$ & $\checkmark$ & $\checkmark$ & $\checkmark$ & $\checkmark$ & $\checkmark$ & $\checkmark$ & $100 \%$ \\
\hline $\begin{array}{l}\text { Kejelasan } \\
\text { petunjuk } \\
\text { kerja atau } \\
\text { deskripsi }\end{array}$ & $\begin{array}{l}\text { Setiap skor atau point } \\
\text { memiliki indikator dan } \\
\text { deskripsi yang jelas }\end{array}$ & $x$ & $\checkmark$ & $x$ & $x$ & $x$ & $x$ & $\checkmark$ & $\checkmark$ & $37.5 \%$ \\
\hline $\begin{array}{l}\text { Skala } \\
\text { peringkat }\end{array}$ & $\begin{array}{l}\text { Rubrik menggunakan } \\
\text { skala peringkat. }\end{array}$ & $\checkmark$ & $\checkmark$ & $\checkmark$ & $\checkmark$ & $\checkmark$ & $\checkmark$ & $\checkmark$ & $\checkmark$ & $100 \%$ \\
\hline $\begin{array}{l}\text { Kriteria- } \\
\text { kriteria di } \\
\text { dalam } \\
\text { rubrik }\end{array}$ & $\begin{array}{lr}\text { Rubrik menggunakan } \\
\text { kriteria-kriteria yang } \\
\text { paling penting sesuai } \\
\text { kinerjanya. }\end{array}$ & $x$ & $x$ & $x$ & $\checkmark$ & $\checkmark$ & $\checkmark$ & $x$ & $\checkmark$ & $50 \%$ \\
\hline $\begin{array}{l}\text { Objektivita } \\
\text { s penilaian }\end{array}$ & \begin{tabular}{lrr}
\multicolumn{3}{l}{ Kriteria didalam rubrik } \\
dapat digunakan & untuk \\
penilaian yang & adil \\
terhadap setiap peserta \\
didik.
\end{tabular} & $x$ & $x$ & $\checkmark$ & $x$ & $\checkmark$ & $\checkmark$ & $\checkmark$ & $x$ & $50 \%$ \\
\hline
\end{tabular}

Berdasarkan tabel di atas, persentase yang paling kecil dapat dilihat pada indikator kejelasan petunjuk kerja atau deskripsi yaitu 37,5\%. Diikuti dengan persentase yang masih kurang yaitu indikator objektivitas penilaian, kejelasan kata-kata dan kriteria-kriteria di dalam rubrik sebesar 50\%. Selanjutnya pada indikator isi rubrik menunjukkan persentase $62,5 \%$. Indikator-indikator yang lainnya sudah baik yaitu sudah hampir memenuhi indikator-indikator pada rubrik penilaian. Berkaitan dengan pembelajaran 2013 yang sudah mengaitkan materi lingkungan, sosial, dan ekonomi secara tidak langsung dapat dilihat juga dari rubrik penilaian berkaitan dengan kemunculan konteks lingkungan, sosial, dan ekonomi dimana pada rubrik yang dianalisis baik itu dari RPP dan buku guru sudah muncul keterampilan atau kinerja berkaitan dengan lingkungan dan sosial sesuai materi yang disampaikan yaitu sebesar $87,5 \%$. Walaupun tidak semua aspek ESD ada dalam satu pembelajaran. Kemudian kaitan kriteria dengan kemampuan berpikir sistem atau holistik pada rubrik penilaian yang dianalisis sudah terlihat pada tugas dan sesuai tujuan pembelajaran yaitu sebesar $75 \%$. Kebanyakan tugasnya yaitu untuk menggali peserta didik berpikir secara utuh tidak terpisah-pisah, diantaranya tugas menganalisis, melihat alam sebagai suatu sistem mengenai kenampakan alam, membuat ringkasan, dan memainkan peran drama.

Berdasarkan hasil analisis mengenai rubrik asesmen kinerja yang diperoleh dari wawancara dengan guru dan dokumentasi, diketahui bahwa indikator kejelasan petunjuk kerja atau deskripsi masih kurang. Hal ini disebabkan guru merasa kesulitan dalam menentukan tugas-tugas kinerja. Guru kelas V di kabupaten dan kota Tasikmalaya menyebutkan bahwa asesmen kinerja apabila dilaksanakan juga hanya menilai produknya saja dan tanpa menggunakan instrumen penilaian contohnya rubrik. Sehingga ketika menggunakan rubrik sebagai penilaian psikomotor atau keterampilan merasa kesulitan dalam menentukan tugas yang jelas. Hasil wawancara tersebut diperkuat dengan hasil analisis dokumentasi dari RPP dan buku guru yang menunjukkan 
1331 Analisis Rubrik Penilaian Berbasis Education for Sustainable Development dan Konteks Berfikir Sistem di Sekolag Dasar - Dewi Andriani, Ghullam Hamdu, Karlimah

DOI : https://doi.org/10.31004/edukatif.v3i4.514

persentase $37,5 \%$. Artinya guru dalam menggunakan rubrik penilaian dirasa masih kesulitan untuk mendeskripsikan kinerjanya dari setiap skor atau point sesuai tingkat penguasaannya. Hal ini sejalan dengan penelitian (Boy, 2019; Puspitasari \& Haryani, 2014) bahwa deskripsi pada rubrik harus menggambarkan apa yang diharapkan pada level atau skor tertentu dengan sederhana menggunakan bahasa anak yang layak, tetapi selama ini rubrik penilaian hanya dibuat dalam kalimat-kalimat panjang tetapi tidak mendeskripsikan kriteria tugas yang sesuai sehingga membutuhkan pemahaman yang lama jika digunakan sebagai panduan penilaian.

Sedangkan untuk objektivitas penilaian diperoleh persentase 50\% dari hasil analisis dokumentasi rubrik pada RPP dan buku guru. Sesuai dengan hasil wawancara hal ini disebabkan karena banyaknya peserta didik dalam setiap kelas sehingga guru kesulitan untuk menentukan rubrik penilaian asesmen kinerja yang sesuai untuk seluruh peserta didik dan terkendalanya waktu dalam penilaian. Menurut Hima (2017) untuk mengatasi objektivitas penilaian dibutuhkan persiapan dalam membuat atau merancang rubrik berkaitan dengan komponen-komponennya. Kemudian perlunya menyiapkan rubrik penilaian jauh-jauh hari sehingga peserta didik sadar akan tujuan pembelajaran yang akan diajarkan. Perlu diketahui bahwa rubrik tidak dijadikan untuk membandingkan peserta didik sehinga rubrik harus dapat mengukur semua kinerja peserta didik (Boy, 2019).

Kemudian indikator kejelasan kata-kata dalam rubrik menunjukkan persentase sebesar 50\% dari hasil analisis dokumentasi. Guru merasa asesmen kinerja tidak terlalu penting sehingga seringkali diabaikan. Dalam pelaksanaanya juga hanya menggunakan hafalan, sedikit sekolah yang sudah menggunakan rubrik untuk pedoman asesmen kinerja. Dengan demikian menurut Zalsalina, Palupi, \& Riyaningsih (2020) menyatakan bahwa bahwa kalimat dalam rubrik penilaian tidak boleh menggunakan kata-kata yang dapat ditafsirkan ganda. Kemudian harus jelas dan bebas dari pernyataan yang tidak relevan dengan kriteria atau tugas yang dilakukan. Penggunaan bahasa juga harus diperhatikan yaitu menggunakan bahasa Indonesia baku dan tidak menggunakan bahasa yang berlaku di daerah setempat.

Indikator lain yang menjadi kendala yaitu kriteria-kriteria di dalam rubrik. Hasil analisis dokumen rubrik penilaian menunjukkan persentase sebesar 50\%. Sesuai dengan hasil wawancara bahwa dalam rubrik penilaian, guru menggunakan kriteria-kriteria yang ada pada buku guru. Hal ini disebabkan guru masih kesulitan untuk menentukan kriteria atau aspek sendiri. Dilihat dari hasil analisis dokumentasi pada buku guru, kriteria rubrik pada pembelajaran 1 sampai pembelajaran 6 hanya sebagian yang menggunakan kriteria yang sangat penting sesuai kinerjanya. Begitu juga dalam pelaksanaan di sekolah dasar berdasarkan kedua RPP masih menggunakan kriteria-kriteria yang sama dengan buku guru tetapi tidak sesuai juga dengan kinerja yang diinginkan, karena adanya modifikasi ketika membuat RPP bisa jadi berkaitan dengan indikator pencapaian kompetensi dan tujuan pembelajaranya. Sebenarnya kriteria-kriteria itu merupakan aspek yang ingin dinilai dari kinerja peserta didik, yang menggambarkan kompetensi, keinginan, dan harapan yang harus dicapai (Meutia, Johar, \& Ahmad, 2013; Segara, 2014). Sejalan dengan hasil penelitian Rosdiana dan Retnawati (2014:75) menunjukkan bahwa dalam menyusun rubrik masih menjadi masalah bagi guru di sekolah. Kesulitan dalam menentukan kriteria penting penilaian, menyusun kriteria penilaian untuk setiap point atau level kemampuan secara deskripsi, serta dalam memberi skor.

Selain itu ada indikator isi rubrik pada analisis dokumentasi yaitu menunjukkan persentase $62.5 \%$. Hal ini dikarenakan dalam rubrik penilaian baik dari RPP dan buku guru masih terdapat komponen-komponen yang belum lengkap, setelah dianalisis rubrik penilaian dari RPP merupakan rubrik penilaian yang ada pada buku guru tetapi tidak digunakan semuanya disesuaikan kembali dengan tujuan pembelajaran. Sehingga ketika RPP dimodifikasi sesuai dengan tujuan pembelajaran di sekolah, perlu diperhatikan rubrik penilaiannya, harus sesuai dengan apa yang diajarkan. Sejalan dengan Nurgiyantoro \& Suyata (2013) terdapat dua hal pokok dalam sebuah rubrik yaitu kriteria dan tingkat capaian kinerja tiap kriteria, yang dinyatakan dalam bentuk skor atau point kemudian disertai dengan deskripsi sesuai tingkat capaiannya.

Selanjutnya mengenai indikator kaitan rubrik dengan kompetensi atau tujuan pembelajaran, ketepatan penskoran atau pemberian point, dan skala peringkat sudah menunjukkan angka yang besar, persentase 


\section{Analisis Rubrik Penilaian Berbasis Education for Sustainable Development dan Konteks Berfikir Sistem di}

Sekolag Dasar - Dewi Andriani, Ghullam Hamdu, Karlimah

DOI : https://doi.org/10.31004/edukatif.v3i4.514

berturut-turut adalah 75\%, 100\%, dan 100\%. Menunjukkan bahwa rubrik yang ada pada RPP dan buku guru sudah sesuai dengan KD, adanya skor, dan adanya skala peringkat yaitu dari kriteria yang diharapkan sampai membutuhkan bimbingan. Menurut Sukreni et al. (2014) dalam penilaian menggunakan rubrik menggunakan skala rating dan skor, setiap indikator yang akan diukur dibuatkan skor berupa angka dan skor tersebut memiliki makna mulai dari kategori sangat baik, baik, cukup baik, kurang, baik, dan tidak baik. Begitu juga dengan kompetensi KI dan KD serta tujuan pembelajaran harus disesuaikan dengan penilaian yang akan digunakan.

Berkaitan dengan pembelajaran yang mengaitkan materi lingkungan, sosial, dan ekonomi di dalam kurikulum 2013 merupakan suatu proses untuk mengenalkan pendidikan untuk pembangunan berkelanjutan atau ESD. Hal ini sesuai dengan hasil wawancara kepada guru di Sekolah Dasar Kabupaten dan Kota Tasikmalaya bahwa sebenarnya tanpa disadari materi tersebut sudah diajarkan, dapat dilihat dari buku tema yang kebanyakan mengambil tema-tema sehari-hari juga berkaitan dengan materi lingkungan, sosial, dan ekonomi. Pada pembelajaran tematik di sekolah dasar, penerapan nilai-nilai ESD dapat dilaksanakan dengan cara menggabungkan beberapa mata pelajaran. Penilaian yang dilaksanakan juga tidak berbeda dengan penilaian yang lainnya, karena pembelajarannya tetap mengacu kepada kurikulum 2013 tetapi peserta didik lebih diajarkan mengenai nilai-nilai ESD yang diintegrasikan ke dalam mata pelajaran. Maka dalam penilaiannya tidak dilakukan tersendiri. Penilaiannya dapat menggunakan rubrik unjuk kerja ataupun berupa ulangan atau ujian. Menurut Lee (2012) salah satu untuk menilai pembelajaran ESD yaitu menggunakan rubrik. Dengan demikian melalui analisis rubrik ingin mengetahui apakah sudah dimunculkan penilaian yang berkaitan dengan materi lingkungan, sosial, dan ekonomi. Secara tidak langsung dapat dilihat pada rubrik yang dianalisis baik itu dari RPP dan buku guru sudah muncul keterampilan atau kinerja berkaitan dengan lingkungan sesuai materi yang disampaikan yaitu sebesar $87,5 \%$. Walaupun tidak semua aspek ESD ada dalam satu pembelajaran.

Di dalam pendidikan untuk pembangunan berkelanjutan diharapkan peserta didik mampu berpikir secara menyeluruh atau dikenal dengan berpikir sistem/holistik. Pendidikan untuk Pembangunan Berkelanjutan memberikan tujuan bersama melalui pengetahuan yang terasa saling bersangkutan (Lundegard et al., 2020). Hal ini sesuai dengan hasil wawancara bahwa dari keenam guru dari 4 sekolah dasar di kabupaten dan kota Tasikmalaya setuju bahwa ESD akan membantu peserta didik memunculkan pemahaman konsep dengan meningkatkan daya ingat, mebiasakan anak dalam sebuah sistem, mencari tahu bagaimana berinteraksi dalam mengatasi permasalahan, melakukan pembiasaan mencintai lingkungan, menghargai sosial, dan berperan dalam masyarakat sehingga akan muncul mengenai kemampuan yang mampu menghubungkan antar konsep yang sebenarnya sudah diajarkan hanya saja tidak secara gambang berpikir sistem. Didukung dengan analisis dokumentasi bahwa kaitan kriteria dengan kemampuan berpikir sistem atau holistik pada rubrik penilaian yang dianalisis sudah terlihat pada tugas dan sesuai tujuan pembelajaran yaitu sebesar $75 \%$. Tugasnya meliputi menggali peserta didik untuk berpikir secara utuh yaitu menganalisis teks bacaan, membuat ringkasan, memainkan drama, membuat suatu gambar dan menjelasan bagian-bagiannya. Sependapat dengan hasil penelitian Clark et al (2017); Raved \& Yarden (2014) menyatakan bahwa kemampuan berpikir sistem dapat diajarkan kepada anak Sekolah Dasar dengan belajar membuat peta konsep, analisis suatu sistem menggunakan ringkasan, menggabungkan pemahaman mengenai sebab dan akibat secara langsung dan tidak langsung.

Oleh karena itu, analisis rubrik penilaian mengenai asesmen kinerja menjadi langkah dalam mengembangkan rubrik yang baik dan sesuai. Analisis dilakukan agar rubrik yang dikembangkan sesuai dengan tujuan pembelajaran yang akan dicapai dan tugas-tugas kinerja peserta didik. Melalui analisis rubrik penilaian, guru dapat mengetahui komponen-komponen apa yang harus ada dalam rubrik, sehingga guru dapat merancang rubrik sendiri atau menggunakan dari buku guru dan disesuaikan kembali dengan RPP yang dibuat agar relevan dengan langkah-langkah yang direncanakan. Berdasarkan wawancara guru kelas V, dari 
1333 Analisis Rubrik Penilaian Berbasis Education for Sustainable Development dan Konteks Berfikir Sistem di Sekolag Dasar - Dewi Andriani, Ghullam Hamdu, Karlimah

DOI : https://doi.org/10.31004/edukatif.v3i4.514

keseluruhan semuanya sama mengalami kendala dalam melakukan asesmen kinerja begitu juga dalam menggunakan pedoman penilaian rubrik. Analisis rubrik penilaian yang dilakukan peneliti untuk mengetahui komponen rubrik yang sudah digunakan di sekolah dasar yaitu RPP 1 dari salah satu sekolah di kabupaten Tasikmalaya dan RPP 2 dari sekolah dasar kota Tasikmalaya serta buku guru yang dianalisis mengambil salah satu yang ada di kelas V yaitu Tema 5 subtema 2 "Hubungan Antar Makhluk Hidup dalam Ekosistem". Analisis dikaitkan dengan pendidikan untuk pembangunan berkelanjutan atau ESD pada pembelajaran kurikulum 2013 dimana keempat Sekolah Dasar yang diteliti semuanya menyebutkan bahwa secara tidak langsung sudah diajarkan mengenai materi lingkungan, sosial, dan ekonomi yang merupakan 3 pilar dari ESD, terlihat melalui buku tema yang digunakan sebagai bahan ajar. Begitu juga dengan menerapkan pembelajaran nilai-nilai ESD, mengarahkan peserta didik belajar berpikir kritis, berpikir secara utuh atau berpikir sistem, serta diharapkan dapat mengatasi permasalahan yang nyata dalam pembelajaran (Tilbury, 2011).

\section{KESIMPULAN}

Berdasarkan hasil penelitian diperoleh kesimpulan bahwa 1). guru masih merasa kesulitan mengenai penggunaan rubrik penilaian khususnya pada asesmen kinerja, 2). sebagian besar guru menggunakan rubrik penilaian dari buku guru sehingga dibutuhkan pengetahuan dalam mengembangkan rubrik sendiri. Implikasi dari peneltian ini adalah guru mempunyai informasi untuk membuat rubrik sendiri dan guru harus menerapkan asesmen kinerja dengan lebih baik, untuk melihat perkembangan peserta didik. Penelitian ini mengaitkan konteks ESD serta berpikir sistem sebagai kemampuan dalam mengaitkan pembelajaran ESD dan kurikulum 2013 dengan menganalisis rubrik penilaian. Penelitian ini memiliki sumber data berupa dokumen asesmen kinerja yang terbatas yaitu hanya 2 RPP dari 4 sekolah yang diteliti sehingga hasil penelitian yang dihasilkan juga terbatas. Hasil penelitian ini bisa digunakan untuk penelitian selanjutnya yaitu mengembangkan rubrik asesmen kinerja yang sesuai dengan komponen-komponen penilaian. Begitu juga dalam pembelajaran kurikulum 2013 yang sudah mengaitkan konteks pendidikan untuk pembangunan berkelanjutan atau ESD dan berpikir sistem secara tidak langsung menjadi solusi untuk membuat kriteria-kriteria yang sesuai dengan pembelajaran. Pembelajaran dengan mengaitkan konteks ESD dan berpikir sistem yaitu dengan mengangkat permasalahan secara nyata dalam kehidupan sehari-hari baik dalam suatu sistem dalam lingkungan, sosial dan ekonomi. Mengarahkan peserta didik untuk menganalisis, membuat ringkasan, dan membuat peta konsep atau latihan berbentuk LKS dengan melakukan beberapa tugas kinerja.

\section{UCAPAN TERIMA KASIH}

Terima kasih kepada orang tua dan dosen pembimbing yang telah membantu dalam proses pembuatan artikel ini berupa dukungan dan doa yang diberikan sehingga penelitian ini dapat dilaksanakan dengan baik.

\section{DAFTAR PUSTAKA}

Agustin, I. D., Suryana, Y., \& Nugaraha, A. (2018). Pengembangan Instrumen Penilaian Kinerja berbasis Outdoor Learning di SD Perkembangan Kurikulum di Indonesia. PEDADIDAKTIKA: Jurnal Ilmiah Pendidikan Guru Sekolah Dasar, 5(1), 206-211.

Andini, A., Sulistiono, \& Budiretnani, D. A. (2014). Analisis Rubrik Penilaian Rencana Pelaksanaan Pembelajaran IPA Kelas IV di Sekolah Dasar Negeri di Kota Kediri Tahun Ajaran 2013/2014. Seminar Nasional X Pendidikan Biologi FKIP UNS Seminar Nasional X Pendidikan Biologi FKIP UNS.

Boy, L. (2019). Pengaruh Metode Pembelajaran Kuantum dan Penilaian Kinerja Berbasis Rubrik Terhadap Hasil Belajar Matematika Siswa disoroti, yaitu pembaharuan kurikulum, peningkatan kualitas 
1334 Analisis Rubrik Penilaian Berbasis Education for Sustainable Development dan Konteks Berfikir Sistem di Sekolag Dasar - Dewi Andriani, Ghullam Hamdu, Karlimah

DOI : https://doi.org/10.31004/edukatif.v3i4.514

pembelajaran, dan efektifitas metode pembelajaran . Kurikulum pendidikan haru. Al-Ta'dib: Jurnal Kajian Ilmu Kependidikan, 12(2), 191-207.

Clarisa, G., Danawan, A., Muslim, M., \& Wijaya, A. F. C. (2020). Penerapan Flipped Classroom dalam Konteks ESD untuk Meningkatkan Kemampuan Kognitif dan Membangun Sustainability Awareness Siswa. Journal of Natural Science and Integration, 3(1), 13. https://doi.org/10.24014/jnsi.v3i1.8953

Clark, S., Petersen, J. E., Frantz, C. M., Roose, D., Ginn, J., \& Daneri, D. R. (2017). Teaching systems thinking to 4 th and 5 th graders using Environmental Dashboard display technology. Plos One, 12(4), $1-11$.

Dewi, Y. F., Asyar, R., \& Hariyadi, B. (2016). Pengembangan Instrumen Penilaian Berbasis Pendekatan Saintifik Kelas IV SD Muatan IPA pada Subtema Hewan dan Tumbuhan di Lingkungan Rumahku. Edu Sains, 5(1), 1-36.

Didham, R. J., \& Ofei-Manu, P. (2020). Adaptive capacity as an educational goal to advance policy for integrating DRR into quality education for sustainable development. International Journal of Disaster Risk Reduction, 47(May 2019), 101631. https://doi.org/10.1016/j.ijdrr.2020.101631

Ernawati. (2020). Peningkatan Kompetensi Guru Dalam Menyusun Rubrik Penilaian Melalui Pembinaan Terstruktur ( Penelitian Tindakan di SDN 1 Cempaka Lampung Utara ) Ernawati Dinas Pendidikan Lampung Utara PENDAHULUAN Guru Sekolah Dasar mempunyai peranan penting karena member. Pedagogia-Jurnal Ilmiah Pendidikan Dasar Indonesia, Vol 2(No 1), 97-106.

Haqiqi, L. Z., Ramdani, A., \& Zulkifli, L. (2018). Analisis Kemampuan Pendidik Dalam Menerapkan Penilaian Autentik Pada Mata Pelajaran Biologi Kelas X Ipa Sma Di Kabupaten Lombok Timur. Jurnal Penelitian Pendidikan IPA, 4(1), 46-55. https://doi.org/10.29303/jppipa.v4i1.60

Hima, A. N. (2017). Penggunaan Rubrik Penilaian : Bagaimana Mahasiswa Memandangnya ? Pendahuluan Mahasiswa dapat dikatakan berhasil dalam suatu pembelajaran jika telah mampu menguasai segala kompetensi yang atas karangan yang telah ditulisnya, sehingga semakin tinggi jumlah. Seminar Nasional Sistem Informasi 2017, (September), 193-202.

Kurniasih, Y., Hamdu, G., \& Lidinillah, D. A. M. (2020). Rubrik Asesmen Kinerja Berpikir Kritis pada Pembelajaran STEM dengan Media Lightning Tamiya Car. Jurnal Ilmiah Sekolah Dasar, 4(2), 174. https://doi.org/10.23887/jisd.v4i2.25172

Kurniawati, D., \& Mawardi. (2021). Pengembangan Instrumen Penilaian Sikap Gotong Royong dalam Pembelajaran Tematik di Sekolah Dasar Abstrak. Edukatif: Jurnal Ilmu Pendidikan, 3(3), 640-648.

Lee, J. C. K. (2012). Education for sustainable development in China. In Chinese Education and Society (Vol. 43). https://doi.org/10.2753/CED1061-1932430207

Listiani, M., Fadiawati, N., \& Rosilawati, I. (2016). Pengembangan Instrumen Asesmen Kinerja Pada Praktikum Sistem dan Lingkungan. Jurnal Pendidikan Dan Pembelajaran Kimia, 5(1), 76-87.

Listyaningrum, R., \& Winahyu, S. E. (2017). Penerapan Penilaian Kinerja Pada Pembelajaran Dasar. Ilmu Pendidikan, Volume 2(1), 92-96.

Lundegard, S. B., Sellgreen, G., \& Demetriades, M. (2020). Belajar Cara Hidup Berkelanjutan (Learning Sustainable Ways). WWF Indonesia.

Mansyur, dkk. (2019). Asesmen Pembelajaran di Sekolah Panduan Bagi Guru dan Calon Guru. Yogyakarta: Pustaka Pelajar. 
1335 Analisis Rubrik Penilaian Berbasis Education for Sustainable Development dan Konteks Berfikir Sistem di Sekolag Dasar - Dewi Andriani, Ghullam Hamdu, Karlimah

DOI : https://doi.org/10.31004/edukatif.v3i4.514

Meutia, H., Johar, R., \& Ahmad, A. (2013). Kemampuan Mahasisa Calon Guru Menerapkan Penilaian Kinerja Untuk Menilai Hasil Belajar Siswa Dalam Pembelajaran Matematika. Jurnal Peluang, 1 Nomor 2(April), $63-70$.

Muhammad, K., \& Mukhlis, M. (2021). Analisis Rubrik Penilaian Biografi pada RPP Bahasa Indonesia. $J$ LELC Journal of Language Eduaction, Linguistics, and Culture, 1(1), 27-36.

Munawati, S. (2017). Pelaksanaan Penilaian Autentik di Sekolah Dasar Negeri Pujokusuman 1 Yogyakarta. Jurnal Pendidikan Guru Sekolah Dasar, 6(2), 21-29. Retrieved from http://journal.student.uny.ac.id/ojs/ojs/index.php/pgsd/article/view/6619/6385

Noor Endah Mochtar, Hasnah Gasim, Hendarman, Noor Indrastuti, Aulia Wijiasih, Cecep Suryana, Kurniati Restuningsih, S. L. T. (2014). Pendidikan untuk Pembangunan Berkelanjutan (Education for Sustainable Development) di Indonesia. In Komisi Nasional Indoneisa untuk UNESCO Kementrian Pendidikan dan Kebudayaan.

Nurgiyantoro, B., \& Suyata, P. (2013). Model Penilaian Otentik dalam Pembelajaran Bahasa. LITERA, 10(2), $114-125$.

Nurlenasari, N., Lidinillah, D. A. M., Nugraha, A., \& Hamdu, G. (2019). Assessing 21 st century skills of fourth-grade student in STEM learning. Jurnal of Physics: Conference Series, 1-7. https://doi.org/10.1088/1742-6596/1318/1/012058

Pendidikan, T. P. P. (2019). Panduan penilaian kinerja (performance assessment) (D. Hadiana \& Asrijanty, eds.). Jakarta: Pusat Penilaian Pendidikan.

Pratiwi, E. D., Arharina, F. P., \& Saputra, H. J. (2020). Analisis Assesment Higher Order Thinking Skills Pada Materi IPA Kelas Tinggi SD N Bugangan 02 Semarang. Elementary School, 21(1), 1-9.

Puspitasari, N., \& Haryani, S. (2014). Pengembangan Rubrik Performance Assessment Pada Praktikum Hidrolisis Garam. Jurnal Inovasi Pendidikan Kimia, 8(1), 1250-1259.

Putri, M. A., Nyeneng, I. D. P., \& Rosidin, U. (2016). Pengembangan Rubrik Penilaian Keterampilan Proses Sains. Journal of Religious Studies, 72(1), 189-193.

Raved, L., \& Yarden, A. (2014). Developing seventh grade students 'systems thinking skills in the context of the human circulatory system. 2(December), 1-11. https://doi.org/10.3389/fpubh.2014.00260

Rosdiana, T., \& Retnawati, H. (2014). Studi Implementasi Pelaksanaan Penilaian pada Kurikulum 2013. Jakarta:Puspendik, Balitbang Kemendikbud.

Segara, N. B. (2014). Penggunaan Rubrik Sebagai Alternative Assesment Pada Mata Kuliah Seminar Studi Sosial. Edunomic, 2(2), 64-69.

Setiawan, H., Sa'dijah, C., \& Akbar, S. (2017). Pengembangan Instrumen Asesmen Autentik Kompetensi Pada Ranah Keterampilan Untuk Pembelajaran Tematik Di Sekolah Dasar. Jurnal Pendidikan, 2 Nomor 7, 874-882. Retrieved from http://journal.um.ac.id/index.php/jptpp/

Sukreni, N. N., Ganing, N. N., Putra, M., Pendidikan, J., Sekolah, G., \& Ganesha, U. P. (2014). Pengaruh Model Pembelajaran Role Playing Berbasis Penilaian Kinerja Terhadap Pelajaran Bahasa Indonesia Siswa Kelas V SD Jurusan Pendidikan Guru Sekolah Dasar, FIP Universitas Pendidikan Ganesha. Jurnal Mimbar PGSD Universitas Pendidikan Ganesha, 2(1).

Supriatna, N., Romadona, N. F., Saputri, A. E., \& Darmayanti, M. (2018). Implementasi Education for Sustainable Development ( Esd ) Melalui Ecopedagogy Dalam. Primaria Educationem Journal, 1(2), 
1336 Analisis Rubrik Penilaian Berbasis Education for Sustainable Development dan Konteks Berfikir Sistem di Sekolag Dasar - Dewi Andriani, Ghullam Hamdu, Karlimah

DOI : https://doi.org/10.31004/edukatif.v3i4.514

80-86. Retrieved from http://journal.unla.ac.id/index.php/pej/article/view/1077/748

Syakur, A. (2017). Education For Sustainable Development (ESD) Sebagai Respon Dari Isu Tantangan Global Melalui Pendidikan Berkarakter Dan Berwawasan Lingkungan Yang Diterapkan Pada Sekolah Dasar, Sekolah Menengah Dan Kejuruan Di Kota Malang. Eduscience, 1(1), 37-47.

Tilbury, D. (2011). Education for sustainable development: An expert review of processes and learning. Unesco, $132 . \quad$ Retrieved from http://scholar.google.com/scholar?hl=en\&btnG=Search\&q=intitle:Education+for+sustainable+developm ent+An+expert+review+of+processes+and+learning\#0

UNESCO. (2017). Education for Sustainable Development Goals-Learning Objectivies. https://doi.org/10.31142/ijtsrd5889

Winarni, E. W. (2021). Pendampingan Rubrik Penilaian BDR Bagi Guru SD Kota Bengkulu Semasa Pandemi COVID-19. Wikrama Parahita: Jurnal Pengabdian Masyarakat, Volume 5(Nomor 1), 65-72.

Wulan, A.R. (2018). Menggunakan Asesmen Kinerja Untuk Pembelajaran Sains dan Penelitian. Bandung: UPI Press.

Yudha, R. P., Masrukan, \& Djuniadi. (2014). Pengembangan Instrumen Asesmen Otentik Unjuk Kerja Materi Bangun Ruang Di Sekolah Dasar. Journal of Educational Research and Evaluation, 3(2). https://doi.org/10.15294/jere

Yunitasari, R., \& Hanifah, U. (2020). Pengaruh Pembelajaran Daring terhadap Minat Belajar Siswa pada Masa COVID 19. Edukatif: Jurnal Ilmu Pendidikan, 2(3), 232-243. https://doi.org/10.31004/edukatif.v2i3.142

Zalsalina, R., Palupi, G., \& Riyaningsih, D. (2020). Penilaian Keterampilan Abad Ke-21. Prosiding Seminar Nasional V 2019 Peran Pendidikan Dalam Konservasi Dan Pengelolaan Lingkungan Berkelanjutan, 340-346. 